\title{
Wheat and Barley Susceptibility and Tolerance to Multiple Isolates of Wheat streak mosaic virus
}

Erik Lehnhoff, Department of Land Resources and Environmental Sciences, Montana State University, Bozeman, MT 59717; Zachariah Miller, Western Agricultural Research Center, Montana State University, Corvallis, MT 59828; Fabian Menalled, Department of Land Resources and Environmental Sciences, Montana State University, Bozeman, MT 59717; and Dai Ito, and Mary Burrows, Department of Plant Sciences and Plant Pathology, Montana State University, Bozeman, MT 59717

\begin{abstract}
Lehnhoff, E., Miller, Z., Menalled, F., Ito, D., and Burrows, M. 2015. Wheat and barley susceptibility and tolerance to multiple isolates of Wheat streak mosaic virus. Plant Dis. 99:1383-1389.

One of the greatest virus disease threats to wheat production in the Great Plains of the USA is Wheat streak mosaic virus (WSMV). Breeding programs have developed wheat varieties that are resistant or tolerant to WSMV infection, but these characteristics are climate dependent, and may also vary by WSMV isolate. We tested 10 spring and nine winter wheat (Triticum aestivum) varieties and two barley (Hordeum vulgare) varieties for resistance and tolerance to one WSMV isolate over four years. In spring wheat and barley, there were year by cultivar interactions in terms of resistance and tolerance. However, in winter wheat, yield losses due to WSMV were relatively consistent across years and varieties. Additionally, we tested the impacts of three WSMV isolates individually

and in a mixture on twelve, two, and twelve varieties of spring wheat, barley, and winter wheat, respectively. Resistance and tolerance varied by isolate and cultivar, but there were no isolate by cultivar interactions. For spring wheat and barley, yield impacts were greater for two of the three single isolates than for the isolate mixture, whereas in winter wheat, the isolate mixture caused greater yield losses than the individual isolates. Overall, the results indicate that resistance and tolerance phenotypes were influenced by environmental conditions and by WSMV isolate or combination of isolates, suggesting that cultivar screening should be conducted over multiple years and with multiple virus isolates.
\end{abstract}

Wheat streak mosaic virus (WSMV) is a pathogen affecting wheat (Triticum aestivum L.), barley (Hordeum vulgare L.), and other cereal grains globally. In the Great Plains of the USA, this pathogen is one of the most problematic viral pests of cereal crop production, responsible for yield losses averaging up to 7\% per year (Appel et al. 2014). The virus is transmitted by the wheat curl mite (WCM, Aceria tosichella Keifer) (Slykhuis et al. 1957), and through wheat seed at low rates (Jones et al. 2005). Both the virus and its vector require living plant hosts for survival and reproduction, so after crop harvest, an alternative host or infected wheat seed is needed until the next crop is planted. WCM and WSMV can infest a large variety of cereal crop and grassy species (Navia et al. 2013), with volunteer wheat being one of the most important alternative hosts between planted crops (Brey et al. 1998).

The susceptibility (probability of infection following pathogen exposure) and tolerance (impacts of infection on growth and reproduction) of host plants to viruses is dependent upon many interacting abiotic and biotic factors including climate, vector, and plant genotype (Hull 2002). Understanding these relationships within the wheatWSMV-WCM disease complex can facilitate the development of disease management practices (Miller et al. 2014). For example, plant-virus interactions are often temperature-dependent (Kassanis 1957). Genes that confer resistance to WSMV do not function well at high temperatures (Seifers et al. 2007; Seifers et al. 2006; Fahim et al. 2012), and additionally, viral replication and movement within the plant are affected by temperature (Zaitlin and Hull 1987). Despite management practices based on knowledge of the seasonal dynamics

Corresponding author: Mary Burrows; E-mail: mburrows@montana.edu

*The $\boldsymbol{e}$-Xtra logo stands for "electronic extra" and indicates that two supplementary figures are published online.

Accepted for publication 6 April 2015.

http://dx.doi.org/10.1094/PDIS-11-14-1205-RE

(C) 2015 The American Phytopathological Society of WCM movement from crops to alternative hosts and back to crops or through transmission in wheat seed (Coutts et al. 2008; Coutts et al. 2014), infection by WSMV is still common. Attempts have been made to control the wheat-WSMV-WCM disease complex through plant resistance to WCM (Carrera et al. 2012) and WSMV (Fahim et al. 2012); however, the utility of these genes is limited due to temperature sensitivity. Furthermore, vectors and viruses often rapidly evolve to overcome single-gene resistance (Harvey et al. 1997; Jones 2009).

The potential of WSMV to overcome plant resistance depends, in part, on the diversity of viral strains within a population. Strain diversity in the field is also important to consider when screening wheat genotypes for WSMV resistance or tolerance. While little is known about the diversity of WSMV in the Northern Great Plains, there may be considerable genetic variation in WSMV populations. McNeil et al. (1996) reported that for five populations in Nebraska, there was as much variation within fields as among counties. Also, Robinson and Murray (2013) reported considerable diversity in the adjacent Pacific Northwest, with two distinct clades being present. Furthermore, Robinson and Murray (2013) found recombination within many of the isolates from wheat samples tested, suggesting that collected plants contained a mixed infection of WSMV isolates. Such diversity of isolates has implications for WSMV resistance breeding programs, as variable virus populations could interact differently with virus-resistance genes (Robinson and Murray 2013). These complications illustrate the importance of utilizing disease-resistant or tolerant varieties as part of an integrated disease management program, rather than relying solely on the breeding of resistant varieties.

Hundreds of wheat varieties are available to growers across the Northern Great Plains, and new varieties are released annually throughout the region. Many of these varieties have not been screened for their susceptibility and tolerance to WSMV. Nevertheless, a proactive and preventive approach for disease management includes the use of resistant varieties when other options such as delayed planting date, volunteer control, wheat seed testing, and management of alternative hosts do not provide definitive disease control. In addition, Seifers et al. (2003) showed that there was variation in the response of crops including maize, pearl millet, 
sorghum, and wheat to $52 \mathrm{WSMV}$ isolates. Thus, given the genotypic diversity of WSMV, it is important to determine if cultivar resistance/ tolerance is specific to WSMV isolates or varies across isolates as, in the former case, screening for WSMV resistance using a single virus isolate may not provide adequate data on resistance/tolerance.

In this multiyear research, we used 12 spring and 12 winter wheat and two barley varieties, to test (i) if there were cultivar differences in the impact of WSMV on host susceptibility (disease incidence rate) and tolerance (based on ability to maintain yield compared with controls), and (ii) if the effects of WSMV were consistent across years, a proxy for environmental variability. Additionally, we (iii) assessed if cultivar disease resistance or tolerance phenotypes were consistent across WSMV isolates or if they are isolate-specific.

\section{Materials and Methods}

Experimental design. Field experiments were conducted from 2008 to 2012 at the Montana State University (MSU) Arthur H. Post Research Farm, five miles west of Bozeman, MT. The soil is an Amsterdam-Quagle silt loam, pH 7.5. Crop species, crop varieties, and WSMV isolates varied by experiment (Table 1). With the exception of Mace which is a WSMV resistant winter wheat cultivar from Nebraska, all wheat and barley varieties are commonly planted in

Table 1. Summary of experiments conducted to assess wheat and barley susceptibility and tolerance to multiple isolates of Wheat streak mosaic virus

\begin{tabular}{|c|c|c|c|}
\hline Year(s) & Crop & Cultivars & Notes \\
\hline $2008-2011$ & Spring wheat & $\begin{array}{l}\text { Amidon, Choteau, Conan, Corbin, Ernest, Fortuna, } \\
\text { Hank, McNeal, Reeder, and Scholar }\end{array}$ & $\begin{array}{l}\text { Assessed effects of WSMV (Conrad isolate) on } 10 \\
\text { spring wheat varieties (Experiment 1). }\end{array}$ \\
\hline 2009-2011 & Barley & Haxby and Metcalfe & $\begin{array}{l}\text { Barley added in second year of previous experiment } \\
\text { (Experiment 1). }\end{array}$ \\
\hline 2011 & Spring wheat & $\begin{array}{l}\text { Amidon, Choteau, and Conan, Corbin, Ernest, Fortuna, } \\
\text { Hank, McNeal, Reeder, Scholar + Duclair, and Vida }\end{array}$ & $\begin{array}{l}\text { Assessed effects of four WSMV isolates (Conrad, } \\
\text { Huntley, Marias, and Mix) (Experiment 2). }\end{array}$ \\
\hline 2008-2011 & Winter wheat & $\begin{array}{l}\text { CDC Falcon, Genou, Jagalene, Ledger, Morgan, Pryor, } \\
\text { Rampart, Tiber, and Yellowstone }\end{array}$ & $\begin{array}{l}\text { Assessed effects of WSMV (Conrad isolate) on nine } \\
\text { winter wheat varieties (Experiment } 3 \text { ). }\end{array}$ \\
\hline 2011 & Winter wheat & $\begin{array}{l}\text { CDC Falcon, Decade, Genou, Jagalene, Jerry, Ledger, } \\
\text { Mace, Morgan, Pryor, Rampart, Tiber, and } \\
\text { Yellowstone }\end{array}$ & $\begin{array}{l}\text { Assessed effects of four WSMV isolates (Conrad, } \\
\text { Huntley, Marias, and Mix) (Experment 4). }\end{array}$ \\
\hline
\end{tabular}
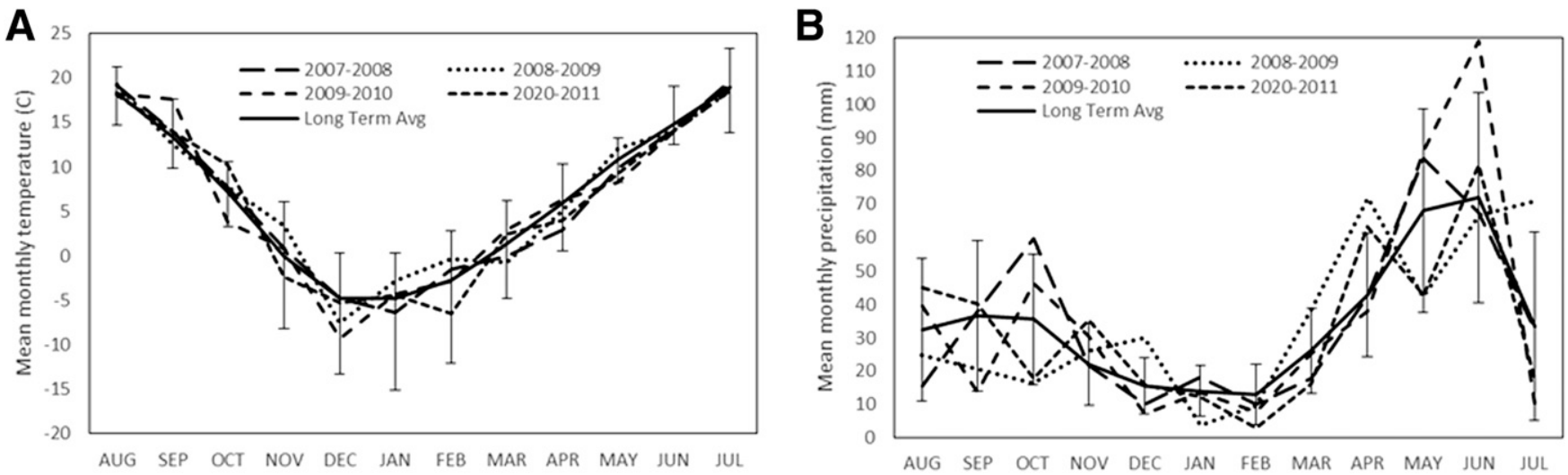

Fig. 1. Mean monthly (A) temperature and (B) precipitation at the Arthur H. Post Research Farm, Bozeman, Montana. The long-term average is from 1966-2014. Error bars around the long-term temperature average are the mean monthly maximum and minimum temperatures, and error bars around the long-term precipitation average are the standard deviation. Data source: Bozeman 6 W Exp Farm weather station, Western Regional Climate Center.

Table 2. Experiment 1: Mean Wheat streak mosaic virus (Conrad isolate) incidence and induced yields in spring wheat and barley ${ }^{\mathrm{Z}}$

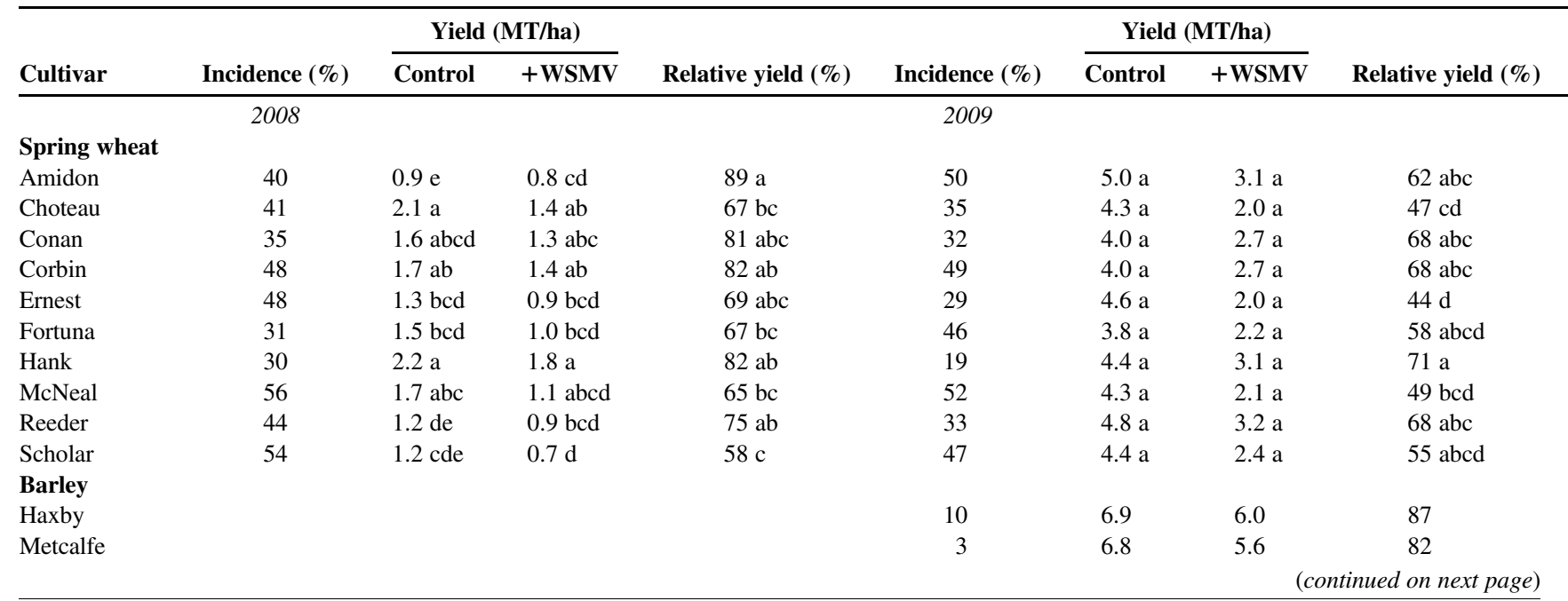

${ }^{\mathrm{z}}$ Different letters (within columns) indicate significant differences among varieties $(P<0.05) . \mathrm{N}=4$ for each cultivar. 
Montana, and none have been reported to be tolerant or resistant to WCM or WSMV. Separate studies included: Experiment 1, 20092011 (comparison of spring wheat and barley varieties inoculated with the Conrad WSMV isolate), 10 spring wheat varieties and two barley varieties inoculated with the Conrad WSMV isolate; Experiment 2, 2011 (impact of three WSMV isolates, plus a mixture of the three, on spring wheat and barley varieties), 12 spring wheat and two barley varieties inoculated with three different WSMV isolates plus an isolate mixture; Experiment 3, 2008-2011 (effect of the Conrad WSMV isolate across winter wheat varieties), nine winter wheat varieties inoculated with the Conrad WSMV isolate; and Experiment 4, 2011 (impact of three WSMV isolates, plus a mixture of the three, on winter wheat varieties), 12 winter wheat varieties inoculated with three different WSMV isolates plus an isolate mixture. Experiments 1 and 3 were conducted over four years, and Experiments 2 and 4 utilized multiple isolates and were conducted in only one year.

While crop and virus genotypes varied, all experiments used the same basic design and methodology. Experiments were randomized complete block designs with crop cultivar as the main plot treatment, and replicated four times. Plots were each $6 \mathrm{~m}$ long by $1.2 \mathrm{~m}$ wide with 5 rows of wheat and $0.3 \mathrm{~m}$ between rows. Split plots ( $3 \mathrm{~m}$ by $1.2 \mathrm{~m}$ ) within main plots were inoculation treatment (WSMV inoculated or control, not inoculated in 2008 or mock inoculated with the buffer solution [see "Virus inoculation" section] only in 2009-2011). All experiments were established in plots that had been fallow the previous growing season and managed according to standard agronomic practices.

Virus inoculation. A WSMV virus isolate from Conrad, MT-collected in 2007 , maintained at $-80^{\circ} \mathrm{C}$, and designated Conrad I (Ito et al. 2012), hereafter Conrad, GenBank Accession No. HM535796.2 - was used throughout this study. Additionally, two other isolates (Huntley, GenBank Accession No. KF887234.1; and Marias, KF887235.1) plus a Mix (Conrad + Huntley + Marias; equal parts and a 1:10 wt/vol dilution volume) were used in one study assessing variation among isolates and whether cultivar performance was consistent across isolates. The Huntley isolate was collected from Huntley, MT in 2007 and the Marias isolate was collected from the Conrad area in 2008. There were no known differentiating biological characteristics in the isolates and the most dissimilar was the Huntley isolate which was $97 \%$ identical, according to BLASTn. The main distinguishing factor was the geographic location from which they were isolated. Virus inoculation was conducted in the spring of each year, as our previous research (Miller et al. 2014) showed that spring inoculation produced greater infection rates. Inoculation was conducted following the protocol of Miller et al. (2014). Briefly, WSMV-infected plants were grown in the greenhouse. Spring wheat (var. Choteau) was inoculated by hand rubbing with isolate stocks diluted 1:10 (wt/vol) in phosphate-buffered saline (PBS, pH 7.2) with $1 \%$ carborundum. After two weeks, these plants were used to inoculate different $35 \times 50$-cm flats of spring wheat for each WSMV isolate at growth stage Feekes 2 (two weeks after planting), using a high-pressure spray gun to deliver the inoculum with $0.5 \%$ carborundum. After $\sim 21$ days, plant tissue was collected and transported on ice from the greenhouse to the field. Leaves were chopped and blended 1:10 (wt/vol) with phosphate-buffered saline and carborundum at $0.5 \%$. Within $1 \mathrm{~h}$ of the blending, crops were inoculated mechanically with a high-pressure Husky siphon feed spray gun (Home Depot, Inc., Atlanta, GA) powered by an air compressor (CompAir, Sidney, OH) from a height of $5 \mathrm{~cm}$ from the top of the plant at a rate of approximately $20 \mathrm{ml}$ inoculum per $30 \mathrm{~cm}^{2}$ at $80 \mathrm{psi}$. Within each plot, virus treatments were not randomized so as to avoid accidentally applying the virus to adjacent plots. All inoculations were applied at Feekes growth stage 3-4.

Virus incidence. WSMV incidence was assessed in all plots in accordance with Miller et al. (2014). Thirty flag leaves were systematically sampled from the center $1 \mathrm{~m}$ of each row (split-plot, thus 150 samples per main plot) of treated plots. We also collected 10 plants per row in control plots. All leaves were processed individually with enzyme linked immunosorbent assay (ELISA) as described by Ito et al. (2012). The absorbance (optical density, OD) values of the healthy wheat (negative controls) were used to identify infected plants. The mean and standard deviation of six negative controls of each cultivar on each plate were calculated and used to set a probabilistic OD threshold at three standard deviations above the mean. Samples above this limit were considered infected.

Yield assessments. Plots were harvested with a Suzue harvestbinder, EN25L-2 (Suzue Manufacturing, Japan). Samples for yield assessments were collected from a 3-m section in the center of each row, and dried for 1 to 2 days before threshing with a Vogel thresher (custom built by Bill's Welding, Pullman, WA). Yield was adjusted to $13 \%$ moisture.

Weather data. Climate was variable during the study period (Fig. 1). Years 2008 and 2010 were generally cooler with fewer frost-free growing days than 2009 and 2011. Precipitation was similar in 2008, 2009 , and 2010, but was reduced relative to the average precipitation for the site in 2011.

Statistical analysis. Incidence data were transformed into logodds prior to analysis. Relative yield (RY) was calculated using the raw yield data as: $\mathrm{RY}=$ (inoculated yield/control yield) $\times 100$. Pearson's correlation coefficient was used to compare overall trends in yields of controls versus inoculated treatments, as well as to evaluate the relationship between incidence and yield. Split-plot analysis of variance (ANOVA) was used to assess differences in WSMV incidence and grain yield across different varieties and WSMV isolates (Experiments 2 and 4). Varieties were modeled as fixed effects at the main plot level and the Year $\times$ Block interaction was included as

Table 2. (continued from preceding page)

\begin{tabular}{|c|c|c|c|c|c|c|c|c|c|}
\hline \multirow[b]{2}{*}{ Cultivar } & \multirow[b]{2}{*}{ Incidence (\%) } & \multicolumn{2}{|c|}{ Yield (MT h/ha) } & \multirow[b]{2}{*}{ Relative yield (\%) } & \multirow[b]{2}{*}{ Incidence (\%) } & \multicolumn{2}{|c|}{ Yield (MT/ha) } & \multirow[b]{2}{*}{ Relative yield (\%) } & \multirow[b]{2}{*}{ Mean incidence $(\%)$} \\
\hline & & Control & +WSMV & & & Control & +WSMV & & \\
\hline & 2010 & & & & 2011 & & & & \\
\hline \multicolumn{10}{|l|}{$\begin{array}{l}\text { Spring } \\
\text { wheat }\end{array}$} \\
\hline Amidon & 46 & $1.9 \mathrm{de}$ & $1.0 \mathrm{bc}$ & $53 \mathrm{ab}$ & 83 & $4.2 \mathrm{ab}$ & $1.0 \mathrm{bc}$ & $24 \mathrm{~d}$ & $56 \mathrm{bc}$ \\
\hline Choteau & 60 & $2.3 \mathrm{~cd}$ & $0.6 \mathrm{~d}$ & $26 \mathrm{~d}$ & 98 & $4.3 \mathrm{ab}$ & $0.5 \mathrm{~d}$ & $12 \mathrm{e}$ & $59 \mathrm{bc}$ \\
\hline Conan & 40 & $3.4 \mathrm{a}$ & $2.1 \mathrm{a}$ & $62 \mathrm{a}$ & 83 & $3.2 \mathrm{~b}$ & $1.9 \mathrm{a}$ & $59 \mathrm{a}$ & $47 \mathrm{c}$ \\
\hline Corbin & 64 & $2.3 \mathrm{bcd}$ & $1.4 \mathrm{ab}$ & $61 \mathrm{ab}$ & 97 & $4.0 \mathrm{ab}$ & $1.6 \mathrm{a}$ & $40 \mathrm{bc}$ & $64 \mathrm{ab}$ \\
\hline Ernest & 71 & 2.0 cde & $0.6 \mathrm{~cd}$ & $30 \mathrm{~d}$ & 81 & $4.3 \mathrm{ab}$ & $0.9 \mathrm{~cd}$ & $21 \mathrm{~d}$ & $57 \mathrm{abc}$ \\
\hline Fortuna & 69 & $1.7 \mathrm{e}$ & $0.7 \mathrm{~cd}$ & $41 \mathrm{bc}$ & 79 & $4.1 \mathrm{ab}$ & $1.5 \mathrm{ab}$ & $37 \mathrm{bc}$ & $56 \mathrm{bc}$ \\
\hline Hank & 45 & $3.2 \mathrm{ab}$ & $2.0 \mathrm{a}$ & $63 \mathrm{a}$ & 86 & $4.2 \mathrm{ab}$ & $2.2 \mathrm{a}$ & $52 \mathrm{ab}$ & $54 \mathrm{c}$ \\
\hline McNeal & 86 & $2.6 \mathrm{abc}$ & $0.9 \mathrm{bcd}$ & $35 \mathrm{~cd}$ & 96 & $4.5 \mathrm{a}$ & $0.6 \mathrm{~d}$ & $13 \mathrm{e}$ & $72 \mathrm{a}$ \\
\hline Reeder & 53 & $2.7 \mathrm{abc}$ & $1.3 \mathrm{ab}$ & $48 \mathrm{ab}$ & 94 & $4.2 \mathrm{ab}$ & $1.5 \mathrm{ab}$ & $37 \mathrm{c}$ & $56 \mathrm{abc}$ \\
\hline Scholar & 70 & $1.7 \mathrm{de}$ & $0.9 \mathrm{bcd}$ & $53 \mathrm{ab}$ & 82 & $4.0 \mathrm{ab}$ & $1.6 \mathrm{a}$ & $40 \mathrm{bc}$ & $63 \mathrm{abc}$ \\
\hline \multicolumn{10}{|l|}{ Barley } \\
\hline Haxby & 0 & 2.8 & 1.8 & 64 & 28 & 3.6 & 2.6 & 72 & $13 \mathrm{~b}$ \\
\hline Metcalfe & 0 & 2.6 & 1.5 & 58 & 11 & 3.3 & 2.6 & 79 & $5 \mathrm{a}$ \\
\hline
\end{tabular}


a random effect. Homogeneity of variance was assessed via Levene's test, and data were log-transformed as necessary. Outliers were detected using a Bonferroni-corrected test of the Studentized residuals. Posthoc means comparisons were made with Tukey's HSD test. For winter wheat, yield data from 2008 and 2010 were excluded from analysis because hail damage affected yields. All analyses were conducted in R version 3.0.0 (R Development Core Team 2013).

\section{Results}

Experiment 1. Comparison of spring wheat and barley varieties inoculated with the Conrad WSMV isolate. In preliminary analyses of WSMV incidence data for spring wheat, two significant outliers were detected and removed from the data. In this and subsequent experiments, analysis of plants from control plots confirmed that the controls remained virus-free. Infection rates differed among years $\left(\mathrm{F}_{3,106}=69.1, P=0.005\right)$ and varieties $\left(\mathrm{F}_{9,106}=4.4, P=0.005\right)$. Differences among varieties were consistent among years (Cultivar $X$ Year interaction, $\mathrm{F}_{27,106}=1.4, P=0.1$ ). Averaged across varieties, incidence rates in spring wheat for 2008-2011 were 43, 39, 60, and $88 \%$, respectively. Posthoc tests indicated that incidence was similar between 2008 and 2009, but increased in each subsequent year (Table 2). Overall, incidence rates were relatively high in spring wheat (mean $=59 \%$ ). Conan and Hank had lower incidence than Corbin and McNeal and Amidon and Fortuna had lower incidence than McNeal (Table 2)

Incidence rates in barley were less than in spring wheat (Table 2) for all years (2009-2011), with a mean barley incidence rate of $9 \%$. When barley varieties were compared among years, there were differences in incidence rates in the two barley varieties and over years (Cultivar $\times$ Year, $\left.\mathrm{F}_{2,9}=7.08, P=0.014\right)$. In 2009, Metcalfe (3\%) was less susceptible than Haxby (10\%). While there were no differences across barley varieties in 2010, in 2011 Metcalfe (11\%) was again less susceptible than Haxby (28\%).

Variance in yield data were similar among years and all data were analyzed in a single model. Yield losses associated with WSMV inoculation differed among spring wheat varieties, but effects were not consistent among years (Cultivar $\times$ Inoculation $\times$ Year interaction, $\mathrm{F}_{22,108}=2.3, P=0.005$ ). In general, losses associated with inoculation increased in all years. There was a moderately strong negative correlation between WSMV incidence and yield (Pearson's correlation coefficient $=-0.55)$. Averaged across varieties, inoculated plots yielded 74, 58, 46, and 32\% of the controls for years 2008-2011, respectively. Even though there was a significant interaction between year and cultivar, certain spring wheat varieties including Hank,
Conan, and Corbin were consistently among the least impacted by WSMV (Table 2), while Choteau, Ernest, and McNeal were consistently among the most affected. For example, relative yields for Hank were $81,71,61$, and $50 \%$ in years 2008 through 2011, respectively, while Choteau relative yields were $65,48,24$, and $12 \%$ for these same years. Impacts of WSMV inoculation to other varieties varied widely from year to year. For example, from 2008 to 2010, Amidon was among the best varieties for relative yield (68\%), yet in 2011, the impacts of WSMV increased and Amidon was among the worst varieties for relative yield (22\%). Reeder and Scholar also exhibited similar shifts in yield losses relative to the other varieties.

The variation in the relative impacts of WSMV among varieties can be explained, in part, by interannual variation in the yields. Yields were relatively lower in 2008 and 2010, averaging 1.5 to $2.5 \mathrm{MT} / \mathrm{ha}$, likely due to drought (2008) and hail damage (2008 and 2010). In these low yielding years, there were more differences among varieties detected in virus-free and inoculated treatments. Yet, higher yielding controls were generally also higher yielding in the inoculated treatments (Pearson's correlation coefficient $=0.52, P<$ 0.001 , across all varieties), but there were exceptions indicating variation in tolerance (e.g., Amidon). In 2009 and 2011, which were relatively high-yielding years, cultivar yields were similar, especially in the uninoculated control plots. There were no yield differences among spring wheat and barley varieties in the controls in 2009 and just one difference in 2011.

The impacts of WSMV on barley yields were relatively small when compared with those of wheat and similar among varieties (Table 2). In most years, the impacts in barley were similar to the least impacted spring wheat varieties (like Hank and Conan). Barley yields and impacts of WSMV were similar between varieties (Cultivar $\mathrm{F}_{1,9}=$ $0.9, P=0.37$ and Cultivar $\times$ Inoculation $\mathrm{F}_{2,18}=0.2, P=0.65$ ). Impacts of WSMV varied among years (Inoculation $\times$ Year $\mathrm{F}_{1,18}=4.3, P=$ $0.05)$, but in contrast to the increasing impacts of WSMV observed in spring wheat, barley impacts peaked in 2010. In 2010, inoculation reduced yields by $40 \%$ (95\% CI 29 to 50\%). In 2009, there were no significant effects of inoculation on yields. In 2011, barley yield impacts were smaller than 2010, averaging $25 \%$ (95\% CI 11 to $38 \%$ ).

Experiment 2. Impact of multiple WSMV isolates on spring wheat and barley varieties. Cultivar-relative WSMV resistance was consistent across WSMV isolates (Cultivar $\times$ Isolate, $\mathrm{F}_{39,126}=$ $1.1, P=0.3$ ), and similar to the 2009-2011 study with the Conrad I isolate (see Experiment 1), infection rates differed across varieties $\left(\mathrm{F}_{13,39}=32.8, P<0.001\right)$. Infectivity rates of the four WSMV inoculation treatments consisting of three isolates and a mixture differed

Table 3. Experiment 2: Mean yields (MT/ha) of spring wheat and barley varieties inoculated with one of three Wheat streak mosaic virus isolates (Conrad, Huntley, or Marias), or a mix of the threey

\begin{tabular}{|c|c|c|c|c|c|c|}
\hline Cultivar & Control & Huntley & Marias & Conrad & Mixed & Across isolates \\
\hline \multicolumn{7}{|c|}{ Spring wheat } \\
\hline Amidon & $4.2 \mathrm{ab}$ & $3.2 \mathrm{ab}$ & $1.6 \mathrm{ab}$ & $1.0 \mathrm{bcd}$ & $2.3 \mathrm{a}$ & $2.0 \mathrm{bcd}$ \\
\hline Choteau & $4.3 \mathrm{ab}$ & $2.4 \mathrm{ab}$ & $0.5 \mathrm{~d}$ & $0.5 \mathrm{~d}$ & $1.9 \mathrm{a}$ & $1.3 \mathrm{~d}$ \\
\hline Conan & $3.2 \mathrm{~b}$ & $2.5 \mathrm{ab}$ & $2.0 \mathrm{ab}$ & $1.9 \mathrm{ab}$ & $2.2 \mathrm{a}$ & $2.1 \mathrm{ab}$ \\
\hline Corbin & $4.0 \mathrm{ab}$ & $2.1 \mathrm{ab}$ & $2.1 \mathrm{ab}$ & $1.6 \mathrm{ab}$ & $1.6 \mathrm{a}$ & $1.9 \mathrm{ab}$ \\
\hline Duclair & $4.4 \mathrm{ab}$ & $2.7 \mathrm{ab}$ & $1.8 \mathrm{ab}$ & $1.9 \mathrm{ab}$ & $2.1 \mathrm{a}$ & $2.1 \mathrm{ab}$ \\
\hline Ernest & $4.3 \mathrm{ab}$ & $1.4 \mathrm{~b}$ & $1.2 \mathrm{bc}$ & $0.9 \mathrm{~cd}$ & $1.6 \mathrm{a}$ & $1.3 \mathrm{~cd}$ \\
\hline Fortuna & $4.1 \mathrm{ab}$ & $2.9 \mathrm{ab}$ & $1.2 \mathrm{ab}$ & $1.5 \mathrm{abc}$ & $2.43 \mathrm{a}$ & $2.0 \mathrm{abc}$ \\
\hline Hank & $4.2 \mathrm{ab}$ & $3.8 \mathrm{a}$ & $2.1 \mathrm{ab}$ & $2.2 \mathrm{a}$ & $2.9 \mathrm{a}$ & $2.87 \mathrm{a}$ \\
\hline McNeal & $4.5 \mathrm{a}$ & $3.0 \mathrm{a}$ & $0.7 \mathrm{~cd}$ & $0.6 \mathrm{~d}$ & $2.3 \mathrm{a}$ & $1.6 \mathrm{~d}$ \\
\hline Reeder & $4.2 \mathrm{ab}$ & $3.0 \mathrm{a}$ & $1.3 \mathrm{ab}$ & $1.5 \mathrm{abc}$ & $2.2 \mathrm{a}$ & $2.0 \mathrm{abc}$ \\
\hline Scholar & $4.0 \mathrm{ab}$ & $3.2 \mathrm{a}$ & $1.9 \mathrm{ab}$ & $1.6 \mathrm{ab}$ & $2.4 \mathrm{a}$ & $2.3 \mathrm{ab}$ \\
\hline Vida & $4.3 \mathrm{ab}$ & $2.9 \mathrm{ab}$ & $1.6 \mathrm{ab}$ & $1.5 \mathrm{abc}$ & $2.1 \mathrm{a}$ & $2.0 \mathrm{abc}$ \\
\hline Mean & $4.1 \mathrm{a}$ & $2.8 \mathrm{~b}$ & $1.5 \mathrm{c}$ & $1.4 \mathrm{c}$ & $2.2 \mathrm{~b}$ & \\
\hline \multicolumn{7}{|l|}{ Barley } \\
\hline Haxby & $3.6 \mathrm{a}$ & $3.6 \mathrm{a}$ & $2.4 \mathrm{a}$ & $2.6 \mathrm{a}$ & $3.1 \mathrm{a}$ & $2.9 \mathrm{a}$ \\
\hline Metcalfe & $3.3 \mathrm{a}$ & $3.0 \mathrm{a}$ & $2.0 \mathrm{a}$ & $2.6 \mathrm{a}$ & $2.5 \mathrm{a}$ & $2.5 \mathrm{a}$ \\
\hline Mean $^{z}$ & $3.5 \mathrm{a}$ & $3.3 \mathrm{a}$ & $2.2 \mathrm{~b}$ & $2.6 \mathrm{ab}$ & $2.8 \mathrm{ab}$ & \\
\hline
\end{tabular}

y Different letters (within columns) indicate significant differences in mean yield among varieties (within species) $(P<0.05)$. N $=4$ for each cultivar and isolate combination.

${ }^{\mathrm{z}}$ Mean values in the last column and rows after crops represent the cultivar and isolate mean yields within cultivar and inoculation treatment, respectively. 
$\left(\mathrm{F}_{3,126}=43.7, P<0.001\right)$. Across varieties, mean infection rates were lower for Marias $(54 \%, P<0.001)$ and Huntley $(63 \%, P=0.001)$ than Conrad (78\%). Infection rates from the Mixture (95\% CI 59.1-81.1) were not different than for Conrad $(P=0.11)$, Huntley $(P=0.44)$, or the mean of all isolates $(65 \%)$, but were greater than Marias $(P=0.005)$. Averaged across isolates, spring wheat infection rates were highest for Choteau $(91 \%)$ and lowest for Scholar $(63 \%)$ and Conan $(65 \%)$. Similar to the previous results with the Conrad isolate, the two barley varieties had lower infection rates (22 and 9\% for Haxby and Metcalfe, respectively) than spring wheat.

The correlations between WSMV incidence and yield were weakly to moderately correlated for the Conrad, Huntley, Marias, and Mixed isolates, with Pearson's correlation coefficients of $-0.51,-0.49,-0.41$, and -0.32 , respectively. Effects of the four WSMV inoculation treatments on yield were analyzed separately in spring wheat and barley. Yields were similar between barley varieties $\left(\mathrm{F}_{1,3}=1.6, P=0.3\right)$, averaging 3.5 MT/ha in the uninoculated controls, but differed among inoculation treatments $\left(\mathrm{F}_{4,24}=5.1, P=0.005\right)$. Inoculation with the Huntley isolates did not affect yields. Yields following inoculation with the Mixed, Con$\mathrm{rad}$, and Marias isolates averaged 2.8, 2.6, and 2.4 MT/ha, respectively, and were significantly lower than the controls.

In spring wheat, the results were more complex. There was a significant Cultivar $\times$ Inoculation interaction $\left(\mathrm{F}_{44,144}=3.7, P<0.001\right)$, but most of the variation in yield was explained by Inoculation treatments $\left(\mathrm{F}_{4,144}=140, P<0.001\right)$. Inoculation with the Mixed isolates and the Huntley isolate produced relatively small yield losses compared with inoculation via Conrad and Marias that consistently reduced yields relative to the controls (Table 3). In addition to

Table 4. Experiment 3: Mean Wheat streak mosaic virus (Conrad isolate) incidence rates in winter wheat ${ }^{\mathrm{z}}$

\begin{tabular}{lllll}
\hline Cultivar & \multicolumn{5}{l}{ Year } \\
\hline & 2008 & 2009 & 2010 & 2011 \\
CDC Falcon & $58 \mathrm{ab}$ & $57 \mathrm{ab}$ & $53 \mathrm{ab}$ & $76 \mathrm{ab}$ \\
Genou & $65 \mathrm{ab}$ & $59 \mathrm{ab}$ & $47 \mathrm{ab}$ & $62 \mathrm{ab}$ \\
Jagalene & $75 \mathrm{a}$ & $58 \mathrm{ab}$ & $49 \mathrm{ab}$ & $63 \mathrm{ab}$ \\
Ledger & $29 \mathrm{~b}$ & $41 \mathrm{~b}$ & $2 \mathrm{~d}$ & $6 \mathrm{c}$ \\
Morgan & $74 \mathrm{ab}$ & $67 \mathrm{a}$ & $68 \mathrm{a}$ & $85 \mathrm{a}$ \\
Pryor & $39 \mathrm{ab}$ & $54 \mathrm{ab}$ & $17 \mathrm{~cd}$ & $52 \mathrm{~b}$ \\
Rampart & $44 \mathrm{ab}$ & $64 \mathrm{ab}$ & $34 \mathrm{abc}$ & $57 \mathrm{ab}$ \\
Tiber & $38 \mathrm{ab}$ & $63 \mathrm{ab}$ & $35 \mathrm{abc}$ & $69 \mathrm{ab}$ \\
Yellowstone & $55 \mathrm{ab}$ & $42 \mathrm{ab}$ & $31 \mathrm{bc}$ & $54 \mathrm{~b}$ \\
Yearly mean & 53 & 56 & 37 & 58 \\
\hline
\end{tabular}

${ }^{\mathrm{z}}$ Different letters (within columns) indicate significant differences among varieties $(P<0.05) . \mathrm{N}=4$ for each cultivar. causing larger yield losses, the effects of the Conrad and Marias isolates were more variable, resulting in unequal variance among treatments (Levene's test, $\mathrm{F}_{59,180}=2.35, P<0.001$ ). Further analysis was split into two groups (Controls + Mixed + Huntley and Conrad + Marias) that meet the assumptions of the analytical model. Within the first group, the effects of inoculation varied among varieties $\left(\mathrm{F}_{22,72}=4.2, P<0.001\right)$. The interaction is largely driven by relatively large impacts of inoculation in varieties that were high yielding in the controls (e.g., Corbin and Ernest in Table 3). Analysis of the data from Huntley and Mixed indicated the cultivar effects were consistent between the two isolates (Cultivar $\times$ Inoculation $\mathrm{F}_{11,36}=1.3$, $P=0.3)$. The Mixed isolate inoculation caused greater yield losses than the Huntley isolate $\left(\mathrm{F}_{1,36}=50.3, P<0.001\right)$. Yields were $19 \%$ lower (95\% C.I. 15 to $24 \%$ ) in the Mixed compared with Huntley. Yield losses from the more damaging Marias and Conrad isolates were similar $\left(\mathrm{F}_{1,36}=0.33, P=0.5\right)$, and cultivar differences were similar between these two isolates $\left(\mathrm{F}_{11,36}=1.3, P=0.2\right)$. Yields differed among varieties $\left(\mathrm{F}_{11,33}=14.4, P<0.0001\right)$ when exposed to these two isolates. The difference among varieties shifted between the relatively less damaging Mixed and Huntley isolates and the more damaging Marias and Conrad isolates (Table 3). As seen in the previous experiment, Hank consistently had relatively high yields when exposed to WSMV. Some varieties (e.g., McNeal) had yields equal to Hank in the Mixed/Huntley treatments but less than Hank in the Marias/Conrad treatments. Other varieties (e.g., Ernest, Corbin) yielded less than Hank in the Mixed/Huntley treatments but were similar to Hank in the Marias/Conrad treatments (Table 3).

Experiment 3. Effect of the Conrad WSMV isolate across winter wheat varieties. Difference in infection rates in WSMV inoculated winter wheat varieties were not consistent across years (Cultivar $\times$ Year interaction $\mathrm{F}_{24,96}=2.53, P=0.01$ ) (Table 4). Ledger was consistently the most resistant cultivar with incidence rates of $29,41,2$, and $6 \%$ for the years 2008 through 2011, respectively. Conversely, Morgan typically had the highest incidence rates with $74,67,68$, and $85 \%$ for these years. Other varieties were generally intermediate; however, there was no consistency in incidence rates over the years.

Yield analysis was restricted to data from 2009 and 2011 as the 2008 and 2010 data were excluded because of hail. There was only a weak correlation between WSMV incidence and yield (Pearson's correlation coefficient $=-0.16)$. Yield losses averaged $14 \%(95 \%$ CI 12-17) compared with controls, and effects of WSMV inoculation were consistent across years (Year $\times$ Inoculation $\mathrm{F}_{1,54}=1.76, P=$ 0.19 ) and varieties (Cultivar $\times$ Inoculation $\mathrm{F}_{8,54}=0.56, P=0.81$ ).

Experiment 4. Impact of multiple WSMV isolates on winter wheat varieties. Spring inoculation of winter wheat varieties with three WSMV isolates plus a mixture showed that infection rates

Table 5. Experiment 4: Mean Wheat streak mosaic virus incidence rates and yield in winter wheat varieties inoculated with one of three Wheat streak mosaic virus isolates (Conrad, Huntley, or Marias), or a mix of Conrad and Huntley

\begin{tabular}{|c|c|c|c|c|c|c|c|c|c|c|c|}
\hline \multirow[b]{2}{*}{ Cultivar } & \multirow{2}{*}{$\begin{array}{l}\text { Control } \\
\text { Yield } \\
\text { (MT/ha) }\end{array}$} & \multicolumn{2}{|c|}{ Huntley } & \multicolumn{2}{|c|}{ Marias } & \multicolumn{2}{|c|}{ Conrad } & \multicolumn{2}{|c|}{ Mixed } & \multicolumn{2}{|c|}{ Cultivar mean $y$} \\
\hline & & $\begin{array}{c}\text { Incidence } \\
(\%)\end{array}$ & $\begin{array}{c}\text { Yield } \\
\text { (MT/ha) }\end{array}$ & $\begin{array}{c}\text { Incidence } \\
(\%)\end{array}$ & $\begin{array}{c}\text { Yield } \\
\text { (MT/ha) }\end{array}$ & $\begin{array}{c}\text { Incidence } \\
(\%)\end{array}$ & $\begin{array}{c}\text { Yield } \\
\text { (MT/ha) }\end{array}$ & $\begin{array}{c}\text { Incidence } \\
(\%)\end{array}$ & $\begin{array}{c}\text { Yield } \\
\text { (MT/ha) }\end{array}$ & $\begin{array}{c}\text { Incidence } \\
(\%)\end{array}$ & $\begin{array}{c}\text { Yield } \\
\text { (MT/ha) }\end{array}$ \\
\hline CDC Falcon & 4.3 & 71 & 3.7 & 40 & 4.0 & 76 & 3.6 & 65 & 3.3 & $63 \mathrm{a}$ & $3.7 \mathrm{bc}$ \\
\hline Decade & 4.2 & 72 & 3.0 & 43 & 3.4 & 70 & 3.4 & 73 & 3.0 & $65 \mathrm{a}$ & $3.2 \mathrm{c}$ \\
\hline Genou & 4.6 & 76 & 3.9 & 30 & 4.0 & 62 & 3.8 & 59 & 3.7 & $57 \mathrm{a}$ & $3.8 \mathrm{abc}$ \\
\hline Jagalene & 4.6 & 68 & 3.4 & 25 & 4.2 & 63 & 3.9 & 63 & 3.4 & $55 \mathrm{a}$ & $3.7 \mathrm{bc}$ \\
\hline Jerry & 4.1 & 34 & 3.7 & 15 & 3.8 & 32 & 3.7 & 43 & 3.8 & $31 \mathrm{~b}$ & $3.7 \mathrm{bc}$ \\
\hline Ledger & 4.0 & 16 & 4.2 & 3 & 4.4 & 6 & 4.0 & 9 & 4.2 & $8 \mathrm{c}$ & $4.2 \mathrm{ab}$ \\
\hline Mace & 4.5 & 6 & 4.6 & 5 & 4.9 & 6 & 4.6 & 9 & 4.2 & $7 \mathrm{c}$ & $4.6 \mathrm{a}$ \\
\hline Morgan & 4.2 & 79 & 3.9 & 50 & 4.0 & 85 & 3.4 & 56 & 3.6 & $67 \mathrm{a}$ & $3.7 \mathrm{bc}$ \\
\hline Pryor & 4.5 & 73 & 3.4 & 33 & 4.2 & 52 & 3.7 & 63 & 2.9 & $55 \mathrm{a}$ & $3.6 \mathrm{bc}$ \\
\hline Rampart & 4.6 & 75 & 3.3 & 33 & 4.0 & 57 & 3.9 & 65 & 3.3 & $58 \mathrm{a}$ & $3.6 \mathrm{bc}$ \\
\hline Tiber & 4.9 & 73 & 4.0 & 43 & 4.4 & 69 & 3.9 & 68 & 2.9 & $63 a$ & $3.8 \mathrm{bc}$ \\
\hline Yellowstone & 4.5 & 65 & 3.6 & 31 & 4.2 & 54 & 4.3 & 51 & 3.5 & $50 \mathrm{a}$ & $3.9 \mathrm{ab}$ \\
\hline Isolate mean ${ }^{\mathrm{z}}$ & $4.4 \mathrm{a}$ & $59 \mathrm{a}$ & $3.7 \mathrm{~b}$ & $29 \mathrm{c}$ & $4.1 \mathrm{a}$ & $53 \mathrm{bc}$ & $3.8 \mathrm{~b}$ & $52 \mathrm{~b}$ & $3.5 \mathrm{c}$ & & \\
\hline
\end{tabular}

\footnotetext{
${ }^{\mathrm{y}}$ Different letters indicate significant differences among varieties $(P<0.05)$. $\mathrm{N}=4$ for each cultivar and isolate combination.
}

${ }^{\mathrm{z}}$ Among incidence and yield means, different letters indicate significant differences between isolates $(P<0.05)$. 
differed among inoculation treatments $\left(\mathrm{F}_{3,108}=36.4, P<0.001\right)$ and varieties $\left(\mathrm{F}_{11,33}=30.8, P<0.001\right)$, but there was no Cultivar $\times$ Isolate interaction $\left(\mathrm{F}_{33,108}=0.9, P=0.5\right)$. Infection rates from the Marias isolate (mean 29\%) were lower than the other isolates. Of the wheat varieties, Mace and Ledger had the lowest infection rates, Jerry was intermediate, and all other varieties had higher rates (Table 5).

Yields were similar among varieties in the control plants. Thus, to evaluate effects on yields, data analysis was restricted to inoculated plants. Overall, the correlation between WSMV incidence and yields varied from weakly to moderately negative for the Marias, Conrad, Huntley, and Mixed isolates (Pearson's correlation coefficients = $-0.16,-0.42,-0.50$, and -0.54 , respectively). Yields differed among varieties (Cultivar $\left.\mathrm{F}_{11,33}=5.3, P<0.001\right)$ and among WSMV isolates (Inoculation $\mathrm{F}_{3,108}=18.53, P<0.001$ ), and there was no interaction between these two variables (Cultivar $\times$ Inoculation $\mathrm{F}_{33,108}=1.2$, $P=0.25$ ). Regardless of WSMV isolates, Mace was generally the highest-yielding cultivar, with Genou, Ledger, and Yellowstone being similar to Mace (Table 5). Decade was consistently the lowest yielding cultivar, and others were intermediate. Averaged across all varieties, the Mixed WSMV isolates caused the greatest yield reductions, followed by the Huntley and Conrad isolates. The Marias isolate induced the least yield losses.

\section{Discussion}

Results of this study are based on mechanical rather than biological (via WCM) inoculation of the crops with WSMV. The relative incidence rates obtained by each of these methods of inoculation are not known and further research is needed to understand the relationship. However, we did find that barley was more susceptible to WCM than mechanical inoculation (Z. Miller et al. unpublished data) in one trial, but the trend across different crops and under different climate conditions was not evaluated. In general, while WCM are believed to be a better vector for WSMV transmission than mechanical inoculation, they are difficult to control in field settings, and mechanical inoculation is a safer option to assure that the virus doesn't spread to adjacent plots. This was evident in our field plots, as we did not detect any evidence of contact transmission to adjacent control plots, which remained virus-free.

In spring wheat and barley, WSMV incidence rates were not consistent across years, indicating that resistance phenotypes were influenced by environment, making it difficult to predict which varieties were the most resistant in a given year. Furthermore, the varieties with the highest incidence rates were not necessarily the ones that experienced the greatest yield losses. However, there was some consistency in which varieties experienced the highest yield losses resulting from WSMV infection. Choteau, Ernest, and McNeal typically had the greatest WSMV induced yield losses and, conversely, Conan and Hank had the lowest yield losses. Corbin had similar relative yields to these despite having high WSMV incidence rates, suggesting higher disease tolerance. Other cultivars, such as Amidon, had the least yield losses in one year and the most in another. It should be noted that the low level of WSMV incidence in barley was not necessarily because of higher resistance, but rather because barley was not readily infected via mechanical inoculation. In another experiment (Z. Miller et al. unpublished data), barley infection via mechanical inoculation was $8 \%$ compared with $32 \%$ via mite inoculation. Overall, the value of tolerance is debatable, however, because tolerant cultivars are still reservoirs for WSMV and provide a source of the WCM and the virus for spread to sensitive cultivars or other crops.

Within winter wheat, there was more consistency in incidence rates, with Ledger being the most resistant and Morgan typically the least resistant. The low levels of infection in Ledger were similar to those in Mace which is resistant via the Wsm-1 gene (Graybosch et al. 2009), indicating that a new form of resistance may be present in Ledger. Overall, winter wheat yields varied by year. Winter wheat generally provided greater yields than spring wheat, which is typical in the Northern Great Plains and one reason spring wheat acres have decreased 0.6 million between 2001 and 2013, while 1.2 million more acres were planted to winter wheat during the same period (NASS 2014). These results indicate that there is considerable variability in both resistance and tolerance in some varieties and this is likely at least partially due to climate effects, including the possibility of greater spread of WSMV by WCM in warmer years. Thus, multiyear field testing is necessary to identify the varieties that are consistently disease resistant or susceptible.

Interannual variation in infection rates differed between fall- and spring-planted cereals, providing additional evidence that variation within spring or fall crops was not due to differences in inoculation (e.g., virus concentration or spray conditions). The warmest and driest year of the study was 2011 and this corresponded with the highest mean WSMV incidence rates in spring wheat and barley. For winter wheat, there were minimal differences in mean cultivar incidence rates in 2008, 2009, and 2011, but incidence rates were lowest in 2010, which was the wettest and one of the coolest years. The winter wheat results are consistent with the pattern of resistance genes being more effective at lower temperatures (Fahim et al. 2012; Seifers et al. 2006; Langham et al. 2001) and also plants without resistance genes having lower infection rates as temperatures decline (Miller et al. 2014).

When a plant is infected simultaneously with multiple isolates of the same virus, there can be interference (e.g., antagonistic interactions) between the isolates resulting in less infection or less impact (Kassanis 1963). This phenomenon may have manifested in spring wheat and barley, where yield loss from the Mixed isolates was less than for the Marias and Conrad isolates. However, this trend was not apparent in winter wheat, where yields were impacted the most by the Mixed isolates and least by Marias. The synergistic effect of the Mixed isolates on winter wheat is similar to the impacts of multiple different viruses. Tatineni et al. (2010) showed that dual infection by WSMV and Triticum mosaic virus (TriMV) increased the accumulation of both of these viruses in wheat compared with single infections. These results indicate that there may be an interaction between wheat type (winter versus spring) and WSMV isolate. Furthermore, within wheat type (winter or spring), isolates impacted yields differently, indicating that adequate tolerance screening may require multiple isolates. While there was not an interaction between isolate and cultivar, the impacts of variable climate on this potential interaction is unknown.

The elucidation of interactions between year and cultivar on resistance and tolerance may inform future breeding efforts, which may be integrated with other disease management strategies. Knowledge of how varieties respond across a range of climatic conditions will facilitate breeding better-adapted varieties. Furthermore, increased understanding of how varieties interact with different WSMV isolates and under contrasting environmental conditions will also be valuable in resistance research as well as cultivar screening programs.

\section{Acknowledgments}

This research was supported with funding from the Montana Wheat and Barley Committee. We express our gratitude to Matt Moffet, Phil Bruckner, Jim Berg, Luther Talbert, Susan Lanning, Bernard Schaff, and the many undergraduates who contributed to this study. Finally, we thank three anonymous reviewers whose comments served to improve this manuscript.

\section{Literature Cited}

Appel, J. A., DeWold, E., Todd, T., and Bockus, W. W. 2014. Kansas Cooperative Plant Disease Survey Report. Preliminary 2014 Kansas Wheat Disease Loss Estimates. Retrieved from http://agriculture.ks.gov/docs/default-source/PP-DiseaseReports-2014/2014-ks-wheat-disease-loss-estimates.pdf, November 2014.

Brey, C. W., Johnson, G. D., and Blodgett, S. L. 1998. Survey of Montana grasses for wheat curl mite (Acari: Eriophyidae), the vector of wheat streak mosaic virus. J. Agric. Entomol. 15:173-181.

Carrera, S. G., Davis, H., Aguirre-Rojas, L., Murugan, M., and Smith, C. M. 2012 Multiple categories of resistance to wheat curl mite (Acari: Eriophyidae) expressed in accessions of Aegilops tauschii. J. Agric. Entomol. 105: $2180-2186$

Coutts, B. A., Banovic, M., Kehoe, M. A., Severtson, D. L., and Jones, R. C. 2014 Epidemiology of Wheat streak mosaic virus in wheat in a Mediterranean-type environment. Eur. J. Plant Pathol. 140:797-813.

Coutts, B. A., Strickland, G. R., Kehoe, M. A., Severtson, D. L., and Jones, R. C. 2008 The epidemiology of Wheat streak mosaic virus in Australia: case histories, gradients, mite vectors, and alternative hosts. Aust. J. Agric. Res. 59:844-853.

Fahim, M., Mechanicos, A., Ayala-Navarrete, L., Haber, S., and Larkin, P. J. 2012. Resistance to Wheat streak mosaic virus- a survey of resources and development of molecular markers. Plant Pathol. 61:425-440. 
Graybosch, R. A., Peterson, C. J., Baenziger, P. S., Baltensperger, D. D., Nelson, L. A., Jin, Y., Kolmer, J., Seabourn, B., French, R., Hein, G., Martin, T. J., Beecher, B., Schwarzacher, T., and Heslop-Harrison, P. 2009. Registration of 'Mace' Hard Red Winter Wheat. J. Plant Registrations. 3:51-56.

Harvey, T. L., Martin, T. J., Seifers, D. L., and Sloderbeck, P. E. 1997. Change in virulence of wheat curl mite detected on TAM 107 wheat. Crop Sci. 37: 624-625.

Hull, R. 2002. Matthews' Plant Virology. Academic Press, San Diego, CA.

Ito, D., Miller, Z., Menalled, F., Moffet, M., and Burrows, M. 2012. Relative susceptibility among alternative host species prevalent in the Great Plains to Wheat streak mosaic virus. Plant Dis. 96:1185-1192.

Jones, R. C. 2009. Plant virus emergence and evolution: Origins, new encounter scenarios, factors driving emergence, effects of changing world conditions, and prospects for control. Virus Res. 141:113-130.

Jones, R. C., Coutts, B. A., Mackie, A. E., and Dwyer, G. I. 2005. Seed transmission of Wheat streak mosaic virus shown unequivocally in wheat. Plant Dis. 89:1048-1050.

Kassanis, B. 1957. Effects of changing temperature on plant virus diseases. Adv. Virus Res. 4:221-241.

Kassanis, B. 1963. Interactions of viruses in plants. Adv. Virus Res. 10:219-55

Langham, M. C., Doxtader, D. C., Haley, S. D., Kalsbeck, S., Little, R. S., and Ibrahim, A. M. 2001. Yield and growth reductions in winter wheat infected with wheat streak mosaic virus. Phytopathology 91:S52.

McNeil, J. E., French, R., Hein, G. L., Baenziger, P. S., and Eskridge, K. M. 1996. Characterization of genetic variability among natural populations of wheat streak mosaic virus. Phytopathology 86:1222-1227.

Miller, Z. J., Menalled, F. D., Ito, D., Moffett, M., and Burrows, M. 2014. Impacts of crop variety and time of inoculation on the susceptibility and tolerance of winter wheat to Wheat streak mosaic virus. Plant Dis. 98:1060-1065.
NASS. 2014. Wheat - All; Crop Acreage, Yield, and Production by County, 20012013. USDA-NASS, Washington, DC. Retrieved from http://www.nass.usda. gov/Data_and_Statistics, November 2014.

Navia, D., De Mendonca, R. S., Skoracka, A., Szydlo, W., Knihinicki, D., Hein, G. L., Valle Da Silva Pereira, P. R., Truol, G., and Lau, D. 2013. Wheat cur mite, Aceria tosichella, and transmitted viruses: an expanding pest complex affecting cereal crops. Exp. Appl. Acarol. 59:95-143.

R Development Core Team. 2013. R: A language and environment for statistical computing. R foundation for Statistical Computing, Vienna, Austria. ISBN 3900051-07-0, URL http://R-project.org

Robinson, M. D., and Murray, T. D. 2013. Genetic Variation of Wheat streak mosaic virus in the United States Pacific Northwest. Phytopathology 103:98-104.

Seifers, D. L., French, R., Stenger, D., and Martin, T. J. 2003. Biological variation among Wheat streak mosaic virus isolates. Phytopathology 93:S78.

Seifers, D. L., Martin, T. J., Harvey, T. L., and Haber, S. 2007. Temperaturesensitive Wheat streak mosaic virus resistance identified in KSO3HW12 wheat. Plant Dis. 91:1029-1033.

Seifers, D. L., Martin, T. J., Harvey, T. L., Haber, S., and Haley, S. D. 2006 Temperature sensitivity and efficacy of Wheat streak mosaic virus resistance derived from CO960293 wheat. Plant Dis. 90:623-628.

Slykhuis, J. T., Andrews, J. E., and Pittman, U. J. 1957. Relation of date of seeding winter wheat in southern Alberta to losses from wheat streak mosaic, root rot, and rust. Can. J. Plant Sci. 37:113-127.

Tatineni, S., Graybosch, R. A., Hein, G. L., Wegulo, S. N., and French, R. 2010. Wheat cultivar-specific disease synergism and alteration of virus accumulation during co-infection with Wheat streak mosaic virus and Triticum mosaic virus. Phytopathology 100:230-238.

Zaitlin, M., and Hull, R. 1987. Plant virus-host interactions. Ann Rev Plant Physiol. 38:291-315. 